Article

\title{
Challenges of Food Waste Governance: An Assessment of European Legislation on Food Waste and Recommendations for Improvement by Economic Instruments
}

\author{
Beatrice Garske $^{1,2, * \mathbb{D}}$, Katharine Heyl ${ }^{1}\left(\mathbb{D}\right.$, Felix Ekardt ${ }^{1,3}$, Lea Moana Weber ${ }^{1}$ \\ and Wiktoria Gradzka ${ }^{1}$ \\ 1 Research Unit Sustainability and Climate Policy, 04229 Leipzig, Germany; \\ katharine.heyl@uni-rostock.de (K.H.); felix.ekardt@uni-rostock.de (F.E.); \\ mail@sustainability-justice-climate.eu (L.M.W.); wiktoria.gradzka@posteo.de (W.G.) \\ 2 Faculty of Agricultural and Environmental Sciences, University of Rostock, 18051 Rostock, Germany \\ 3 Faculty of Law and Interdisciplinary Faculty, University of Rostock, 18051 Rostock, Germany \\ * Correspondence: beatrice.garske@uni-rostock.de
}

Received: 24 June 2020; Accepted: 13 July 2020; Published: 16 July 2020

\begin{abstract}
Food is wasted throughout the entire food supply chain-from agricultural production to the household level. This has negative impacts on natural resources and the environment. At the same time, food waste is undermining the global target of food security. In turn, reducing food waste can minimise the environmental effects of agriculture on climate, biodiversity, soils, water bodies and the atmosphere. All of this is reflected in the fact that food waste is subject to various legal acts of the European Union and that it is also a major subject in the new EU Farm to Fork Strategy from May 2020. Supported by an analysis of the diffuse empirical data on food waste, the purpose of this article is to analyse the current EU legislation on food waste and its reduction to answer the following research questions: How is food waste integrated into European policies? What is the impact of European legislation on food waste? Is European legislation sufficient to trigger not only food waste reduction but also comprehensive changes in the agricultural and food sector to support global climate and environmental targets as set in the Paris Agreement and the Convention on Biological Diversity? Which instruments are the most suitable to do so? Methodologically, a qualitative governance analysis is applied. It is found that relevant legal acts for governing food waste include circular economy and waste law, the Common Agricultural Policy and the Common Fisheries Policy as well as food law, while international environmental targets serve as an overarching measure for governance analysis. The legal analysis shows that existing legislation lacks steering effect to significantly reduce food waste. To overcome current governance problems, the article introduces economic policy instruments. It is concluded that quantity control focusing on overarching parameters such as fossil fuels or animal-derived products has not only the potential to reduce food waste by increasing food prices but can also address the multiple interlinked environmental challenges of the agricultural and food sector.
\end{abstract}

Keywords: food waste; food security; food supply chain; resource conservation; circular economy; Common Agricultural Policy; agricultural law; environmental law; economic instruments

\section{Introduction}

Feeding a growing world population is a global challenge. The reduction of food waste is considered to be one measure to meet this challenge. In fact, it has been estimated that halving food waste could meet the demand for food of the growing population [1] (p. 477). At the same time, 
wasting food and thus using resources inefficiently further exaggerates the environmental problems (e.g., land use changes, greenhouse gas emissions, biodiversity loss) that are related to agricultural production [2-4].

In addition, the issue of food waste furthermore highlights the distributive issues of a non-sustainable global food and agriculture system. For example, it is estimated that 33 million people in the EU cannot afford a quality meal every second day making food assistance indispensable for a large part of population in the Member States. Simultaneously, a relevant amount of food is wasted and overweight and obesity are rising [4] (p. 4) [5,6].

The EU is committed to the (legally non-binding) UN Sustainable Development Goal 12.3, which aims at halving per capita food waste at retail and consumer levels by 2030 [7] (p. 22). More recently, the European Commission furthermore considers food waste as key to achieving sustainability within the framework of the new Farm to Fork Strategy published in May 2020 [4] (p. 14). The strategy points out that reducing food waste is in line with policies targeting food safety, the recovery of nutrients and raw materials, biodiversity conservation, sustainable waste management and the promotion of renewable energy [4] (p. 14). This is why the Commission intends to investigate food waste and explore ways of preventing food waste in all sectors [4] (p. 15).

The purpose of this article is to assess the integration of food waste in European policies as well the impact of the European legislation on food waste prevention. In addition to that, the article proposes optimised governance options to reduce food waste effectively. Yet, the complexity of the food waste issue impedes a good and clear understanding of the underlying problem. Therefore, the article builds on an analysis of the empirical material on food waste, which includes the resources wastage and greenhouse gas emissions caused by food waste (Section 3.1), the plethora of definitions of food waste (Section 3.2), the quantification of food waste on global and European level (Section 3.3), the localisation of food waste in the food supply chain (Section 3.4) as well as the causes and drivers of food waste and their implications for governance solutions (Sections 4 and 5). Taking this empirical data as a basis, the legal acts of the EU relevant for food waste are analysed by applying a qualitative governance analysis. While international environmental targets on climate protection and biodiversity conservation serve as a framework (Section 4.1), circular economy and waste law (Section 4.2), the Common Agricultural Policy and the Common Fisheries Policy (Section 4.3) as well as the law of food safety and packaging, norms and date labelling (Section 4.4) are identified as relevant legal areas and therefore evaluated with regard to their impact on the reduction of food waste. Furthermore, legal aspects of dumpster diving, food disposal and foodsharing (Section 4.5) as well as of food donations (Section 4.6) are assessed. The last section discusses the effects of existing law as well as its shortcomings measured against the aim of a significant reduction of food waste as implied by global environmental targets. At the end, economic governance instruments are proposed to overcome the deficits of existing law and to tackle the problems of food waste and agricultural environmental challenges comprehensively.

\section{Materials and Methods}

Methodically, the article reviews the relevant literature on food waste on an international, European and national level in a first step. In addition to the international scientific literature on environmental damages caused by food waste, data from studies published by e.g., the Food and Agricultural Organisation of the United Nations (FAO) and further UN Organisations such as the Intergovernmental Panel on Climate Change (IPCC), the European Commission and the European Court of Auditors are analysed and compared regarding their information on the quantities, locations and causes of food waste. These insights are necessary to gain a clear understanding of food waste (What is food waste? How much food is wasted? Where and why food is wasted?) to then identify the most effective starting points for governance instruments and to develop effective governance instruments to minimise food waste.

In a second step, based on the analysis of empirical data, relevant legal acts for governing food waste are identified supported by relevant literature on sustainability governance in the agricultural 
and food sector and in particular on food waste (e.g., the publication on food waste of the European Court of Auditors [8] and the FUSIONS report [9]) and by using the EUR-Lex database [10] which collects and publishes all official documents of European Institutions. Then, the legislation's ability to reduce food waste effectively - either directly or indirectly—is assessed. To this end, a multi-method governance analysis (or steering analysis) is applied. The analysis evaluates the impact of real or proposed governance instruments towards a given normative objective by taking findings of research on human behaviour and typical governance problems into account [11-16].

As regards policy objectives, this paper assesses existing and possible future instruments not only under the auspices of food waste specific targets of European legislation but also of the international binding targets of the Paris Agreement [17] and the Convention on Biological Diversity [18]. Both objectives imply comprehensive changes in the agricultural and food sector (see in detail Section 4.1) including a significant reduction food waste. The research questions for the governance analysis were: How is food waste integrated into European policies? What is the impact of European legislation on food waste? Is European legislation sufficient to trigger not only food waste reduction but also comprehensive changes in the agricultural and food sector to support global climate and environmental targets as set in the Paris Agreement and the Convention on Biological Diversity? Which instruments are the most suitable to do so?

However, the effects of policy instruments can frequently not be assessed by simply observing them, especially since the observation of impacts of optimised policy instruments that have not yet or only under different conditions existed in reality is not possible. A suitable method to assess such new instruments is the qualitative governance analysis.

By building on behavioural scientific findings from various disciplines such as sociology, economics, psychology, ethnology, etc., the potential reaction of addressees of governance instruments can be anticipated. Experiments, surveys, participant observation, socio-biological analyses and other methods show that motivational factors, which determine human behaviour, are in particular self-interest, structural problems such as path dependencies and problems of collective goods, values, conceptions of normality, emotional constraints such as convenience, denial, routines, group thinking, scapegoating and the tendency to make excuses $[16,19,20]$. Based on these insights into the behavioural motivation of consumers, producers, entrepreneurs, politicians, etc. and on empirical findings, typical governance problems in the field of sustainability can be identified. These include rebound effects, spatial and sectoral shifting effects, lack of rigour, problems of depicting and enforcement. The problems diminish the effectiveness of governance instruments. They are to be avoided when developing future instruments aiming at given environmental targets such as food waste reduction $[11,12,16]$.

Rebound effects refer to the fact that the improvement of e.g., the resource efficiency of single products or processes do not prevent an increase of the overall use of these products or processes. Thus, the overall ecological benefit is compensated or compromised (e.g., less food waste per restaurant is allowed but more restaurants are producing food waste). Shifting effects occur when the policy measure in one region or sector results in undesired developments in another region or sector, so that the resource use, the emission or the environmental issue is shifted instead of solved (e.g., less food waste occurs at production level in one country but food imports increase). The lack of rigour describes the gap between a foreseeable effect of a chosen instrument and the given environmental targets (e.g., the aim is to halve food waste but the instruments chosen are voluntary for all addressees). Problems of depicting refer to the fact that sustainability challenges such as food waste production at various steps of the food supply chain are frequently hard to measure, to calculate and to monitor, which also makes it more difficult to address these issues accurately by governance instruments (e.g., the instrument aims at limiting food waste at the household level by a certain amount but a baseline value of food waste in every single household is missing; see Section 3.2). Enforcement problems exist especially in the food and agricultural sector due to a large number of norm addressees, products and processes that all have to be monitored. This is why a policy instrument may not be 
implemented in practice effectively and violations may not be sanctioned. In addition to that, high complexity of the subject to be regulated impedes the enforcement of a rule (e.g., again the measurement of food waste of households) $[11,12,16]$.

Based on these insights, the qualitative governance analysis applied in this article not only assesses the integration and impact of food waste measures in existing EU policies regarding food waste reduction but also assesses the effectiveness of existing and newly proposed governance instruments against their ability to respond to motivational factors of human behaviour and to avoid typical governance problems-measured against the respective environmental targets.

\section{Results of the Empirical Analysis as Basis for the Legal Analysis}

\subsection{Food Waste, Resource Wastage and Greenhouse Gas Emissions}

By wasting food not only the food itself, but all resources and sink capacities, which have been utilised for the production, processing and transportation of food are also wasted. Thus, in addition to concerns over food security $[1,21,22]$ (p. 90) [23] (p. 1), food waste has direct implications for the multiple interlinked environmental impacts which are associated with the use of fertile soils, fresh water, fertilisers, energy and the release of greenhouse gases for producing food [24,25] (pp. 49-55) [26] (p. 98) [27] (p. 253) [4] (pp. 4, 14, 15) [16]. At the same time, an increasing demand for agricultural land to feed a growing population puts further pressure on natural resources [28] (p. 924) [29] (p. 12342). Land use changes such as the conversion of forests into agricultural land have a negative impact on biodiversity [2] (p. 12) [30] (p. 1) and ultimately increase the greenhouse gas emissions of food waste [31] (p. 41). Animal-derived products and meat in particular have been associated with substantial resource wastage. While livestock production as a whole requires large quantities of agricultural land [22] (p. 94), studies frequently point towards the resource-intensive production (e.g., fertilisers, freshwater and land) of meat products. Thus, even though meat products only account for a small share of the wasted food, it is the resource-intensity of these products that gives them a prominent role in the context of food waste [32] (p. 1) [24] (p. 52) [26] (pp. 107-109) [33] (p. 282).

Approximately one third of the freshwater resources and one quarter of the fertilisers used to produce food in the EU are wasted [1] (p. 483). Non-sustainable use of fertilisers is directly linked to multiple negative environmental impacts. The accumulation of nutrients in agricultural soils is a major factor that causes nutrient losses in the environment and eutrophication of water bodies with negative effects on biodiversity [34] (p. 3-9) [15] (pp. 1, 2) [35] (p. 3). In addition, the application of fertilisers (and plant protection products) can contaminate soils with organic pollutants and heavy metals such as cadmium from fertilisers containing phosphate rock [36] (p. 11) [15] (p. 8). Additionally, phosphate rock is a scarce resource, which has led the European Commission to add phosphate rock to the list of critical raw materials in 2014 [37]. Finally, the production of synthetic nitrogen fertilisers is extremely energy intensive and storing and applying nitrogen fertilisers causes the emission of greenhouse gas intensive nitrous oxide [11] (pp. 4-6) [38] (pp. 8-13).

In addition to nitrous oxide, the agricultural sector in general is a major source of greenhouse gases. The IPCC estimates that more than one quarter of the anthropogenic greenhouse gas emissions are caused by agriculture, forestry and other land use [3] (p. 10). The FAO, building on its study from 2011, estimates that $4.4 \mathrm{Gt}$ of $\mathrm{CO}_{2}$ equivalents were related to food waste (including land use change associated with the food wastage) in 2011 which accounts for 8 percent of the total global greenhouse gas emissions. If food waste were a country, it would be the third largest emitter in the world after China and the USA [39] (p. 1). In Europe, the emissions related to food waste account for 3 percent of the total greenhouse gas emissions. Globally, the major contributors to the carbon footprint of food waste are cereals ( 34 percent) and animal-derived products ( 33 percent), while the greenhouse gas emissions per kilogram of product are extremely high for meat products [24] (pp. 16-18) [40] (pp. 721, 724). In the USA, for example, beef alone contributes 16 percent of the greenhouse gas emissions of food waste, while it accounts for only 2 percent of food waste by weight [41] (p. 431). At last, despite the fact 
that landfilled food waste generates the greenhouse gas intensive methane [42] (p. 383) [43] (p. 421) [21], it has been estimated that approximately 45 percent of wasted food is landfilled [44] (p. 115) [26] (pp. 103-104). Both, a reduction of animal-derived food products [45] (p. 29) [32] (p. 1, 13, 14) [11] (pp. 7,8$)$ and the reduction of food waste are therefore considered to be meaningful strategies in combating climate change [46] (p. 41) [28] (p. 924) [40] (p. 721) [23] (pp. 1, 5) [47] (p. 519) [22] (pp. 97-100).

\subsection{Defining and Quantifying Food Waste}

In order to develop effective strategies and governance instruments to minimise food waste, a clear understanding of the underlying problem is needed. However, despite the growing number of studies on food waste, significant issues with the existing data (and the lack of thereof) remain. In addition, uncertainty is caused by e.g., the plethora of definitions. Thus, in the following section an overview of these two interconnected issues is provided. Some studies distinguish between food wastage produced in the early steps of the food supply chain, called food losses, and food wastage that is produced at the end of the food supply chain, called food waste [1] (p. 477) [40] (p. 723) [48] (p. 3065) [22,49-51] (p. 110). Yet, it has been pointed out that the steps of the food supply chain cannot be universally applied to different food products [52]. Thus, in contrast, other studies refer to 'food waste' and 'food losses' synonymously as 'food waste' $[23,25,44,53]$, which is the approach adopted in this article.

The Food Use for Social Innovation by Optimising Waste Prevention Strategies (FUSIONS) project funded by the European Commission defines food waste as 'the fractions of »food and inedible parts of food removed from the food supply chain « to be recovered or disposed (including-composted, crops ploughed in/not harvested, anaerobic digestion, bioenergy production, co-generation, incineration, disposal to sewer, landfill or discarded to sea)' [25] (p. 23). There is disagreement in various studies whether edible and inedible parts (e.g., egg shells and coffee grounds) should be considered [25] (p. 6) $[5,26,44,54]$ or not $[49,51]$, and if the intended uses of the food are considered $[25,49,54,55]$. Some studies furthermore distinguish between avoidable, possible avoidable and unavoidable food waste originating from edible food parts $[44,56]$ or consider overconsumption $[57,58]$ in their analysis [23] (p. 1).

Directly linked to the lack of a consistent definition is the challenge to quantify food waste [59] (p. 1148). The FAO has investigated the extent of food waste and finds that globally, approximately one third of the food which is produced for human consumption is wasted [22,49]. Per capita food waste in Europe is estimated at 280-300 kg/year [49] (pp. 4, 5) [60] (p. 683). In contrast, in 2010, a study that was commissioned by the European Commission estimates that annually $89 \mathrm{Mt}$ food is wasted (EU) which corresponds to 'only' $179 \mathrm{~kg} /$ year/capita [44] (based on EUROSTAT and national studies). Similar amounts (173 kg/year/capita) —accounting for 20 percent of total food produced-have been estimated by a study of the FUSIONS project [26] (p. 98) (based on [5]) [4] (p. 4). The diverging results are rooted in different data bases, baseline years, methods applied [61] (pp. 6618, 6622-6623) and the inclusion of Russia and food waste of agricultural production in the FAO study. It has furthermore been acknowledged that EUROSTAT data [44] is subject to large uncertainties because there is no standardised method for Member States to collect the data which is then provided in EUROSTAT [60] (pp. 683, 685).

In addition, data are frequently outdated and concentrated on specific regions and steps of the food supply chain (i.e., household level) [5] (p. 13) [61] (p. 6618) [60] (pp. 683-685). However, because food supply chains are highly complex as they can oftentimes span across the globe and involve numerous actors and processes, measuring food waste has become highly costly [55] (p. 3). In turn, researchers define boundaries within the food supply chain (e.g., primary production, processing, transportation). The resulting variety of food supply chain concepts (see for a four-step food supply chain [44], for a five-step food supply chain [1] (p. 477) [26] (p. 98) and for a seven-step food supply chain [62] (p. 37); 
see also [50] (p. 604))—alongside the variety of definitions and different methods applied-impedes the comparison of results (see FAO [24,49] and EU-Studies [5,44] above) [61] (p. 6618).

\subsection{Localising Food Waste}

To identify the most effective starting points for governance instruments, localising food wastage is necessary. Whereas in North America and Europe, food waste primarily occurs at the end of the food supply chain (retail and consumption stage), in 'developing countries' food waste occurs at the early stages of the food supply chain (production, harvest and processing) [21,49] (p. 5) [24] (pp. 13, 14) [1] (pp. 477, 482) [40] (pp. 721, 726). Globally, the highest potential for improvements is seen in agricultural production ( -47 percent) and the consumption stage ( -86 percent). The largest potential for reduction in the overall food supply are North America and Europe (-63 percent). However, there may be less incentives to reduce food waste in those regions as there is little need for extra food supply [63] because demand is widely met.

The results of Monier et al. [44] show that in the EU, households produce the largest share (42 percent) of food waste, followed by manufacturing (39 percent), food service/catering (14 percent) and retail/wholesale (5 percent) [44,54] (pp. 479, 483-485). Yet, agricultural food waste is outside the scope of this study [44] (p. 13) which likely distorts the results as e.g., the FAO finds that agricultural waste in Europe (not EU) - depending on the commodity group-accounts for up to 20 percent of food wasted along the supply chain [24] (p. 43).

In the EU, fresh fruit and vegetables account for the highest amount of food waste followed by cereals, meat products (incl. fish) and dairy products. The reasons for the large amount of wasted fresh fruit and vegetables include a relatively short shelf-life, higher production and consumption quantities and comparatively low prices which can lead to overpurchasing [54] (p. 479) [32] (p. 1). Furthermore, although the consumption stage accounts for the largest share of all food wasted, waste generation of some food products occurs at other stages of the food supply chain. For example, large shares of meat products are wasted during manufacturing while fresh fruit and vegetables are predominantly wasted at the household level [54] (pp. 497, 483-485) [64] (pp. 21, 22) [31] (pp. 42, 43).

\subsection{Causes and Drivers of Food Waste and Implications for Governance Solutions}

At last, the development of effective governance instruments to combat food waste requires knowledge on the causes and drivers for food waste as well as human behaviour itself [16] (pp. 68-104) [65] (p. 27) (see Section 2). Studies have investigated the drivers and causes of food waste at different steps of the food supply chain $[62,66]$ with spatial and/or sectoral foci $[31,64,67-69]$. Differences between industrialised and non-industrialised countries have been identified. Yet, because food supply chains can cross national, regional and continental borders, food waste in non-industrialised countries has relevance for industrialised countries. The identified drivers that impact food waste occurrence in industrialised countries are an ageing population and growth in single-person households, while urbanisation shifts in dietary and increasing global trade impact food waste occurrence in non-industrialised countries [48] (pp. 3065-3067) [68] (p. 648) [40] (pp. 671, 728) [22] (pp. 13-16). Due to a lack of data, the FAO assumes that food waste increases with increasing regional average food consumption level, GDP per capita and urbanisation level. Yet, the FAO itself acknowledges that this linear relationship is uncertain [24] (p. 37).

With regard to the different steps along the food supply chain, process losses, technical disturbances and quality management occur as major causes for food waste besides packaging/labelling mistakes. In addition, an increasing demand for fresh products as well as the corresponding selective processes to ensure freshness of food products which partly result from food safety standards contribute to food waste along the food supply chain [70] (pp. 49, 50) [68] (p. 648) [62] (pp. 37, 57).

Studies which investigate causes and drivers of food waste at the household level repeatedly refer to the interdependency of multiple factors that lead to the wastage of food. In addition to the global 
drivers discussed before and besides specific behaviours such as failure to compile and comply with a shopping list, the composition of households (number of members, income, demography), organisational aspects, routines and concepts of normality impact food waste occurrence [71] (p. 43) [72] (p. 978) [73] (p. 429) [25] (pp. 57-70) [74] (p. 6). Furthermore, confusion related to expiration labels (the date of minimum durability and the 'use by' date) play a role (see Section 4.4) [64,69] (p. 118). In turn, on the one hand convenience, self-interest (time constraints) and scapegoating get in the way of avoiding food wastage [75] (pp. 15, 18-20) [76] (pp. 4,5), while on the other hand the motivation to save money and to feel less guilty (rather than concerns for the environment [71] (pp. 43, 47-49) [75] (pp. 15, 20) [76] (p. 3) [72] (p. 978)) encourage people to reduce food waste [71] (pp. 43, 47-49) [72] (p. 978).

These observations-which include all actors along the food supply chain, i.e., farmer to consumer-confirm the fundamental conditions of social change and human motivation as discussed in Section 2: knowledge and norms are important factors, but even more so self-interest calculation, path dependencies and conceptions of normality as well as emotions [16]. Thus, as is the case with other sustainability challenges, simply expanding knowledge on food waste issues will not be an effective governance approach. Furthermore, targeting single industries, actors or problems alone will not be effective either. Instead, in order to achieve legally binding environmental objectives, the most promising governance approach is an instrument that controls quantities $[16,77]$.

\section{Results of the Legal Analysis: Food Waste Governance in the EU}

\subsection{Relevant Environmental Targets}

The following section assesses to what extent current EU law addresses the aforementioned issues that are related to food waste. Two legally binding international agreements provide the general framework for environmental policy-they set the objectives that policy instruments have to achieve. Article 2 paragraph 1 Paris Agreement, which builds on the United Nations Framework on Climate Change (UNFCCC) [78], aims to hold the increase of global temperature to well below $2{ }^{\circ} \mathrm{C}$, pursuing efforts to limit the temperature increase to $1.5^{\circ} \mathrm{C}$ above pre-industrial levels. The Aichi Targets of the Convention on Biological Diversity aims to halt biodiversity loss. Both agreements require significantly reduced animal farming [11] and zero fossil fuels in all sectors worldwide in about two decades [79], which also implies major changes in agriculture [16,77,80,81]. Last but not least, the EU Nitrates Directive [82] and the EU Water Framework Directive [83] point in the same direction, especially with regard to avoiding nutrient hotspots due to regional high livestock densities [15]. At the same time, mechanisms which can compensate for residual emissions of a post-fossil agriculture with strongly reduced livestock numbers, e.g., afforestation and rewetting of peatlands, have to be enhanced. However, wasting food puts additional pressure on those mechanism because of the associated high use of land and resources and its greenhouse gas intensity.

In addition to the Paris Agreement and the Convention on Biological Diversity, the Sustainable Development Goals (SDGs) of the UN [84] (pp. 9-11) [7] (pp. 15, 16), which were adopted in 2015 as part of the Agenda 2030, touch upon sustainable agriculture and food waste. This includes SDG 2 'end hunger', SDG 12 'responsible consumption and production' and SDG 15 'life on land'. More specifically, SDG 12.3 requires halving per capita global food waste at the retail and consumer levels by 2030 and reduce food losses along production and supply chains, including post-harvest losses [7] (p. 22) [81,85,86] (pp. 12,13). In response to the SDGs and as part of the 'Zero Hunger Challenge' of the UN [87], SAVE FOOD, which is a global initiative to reduce food waste [88] and the FAO Platform on the Measurement and Reduction of Food Loss and Waste [89] were launched. Thus, despite being vague in some details and not-legally binding, the SDGs can set an overall direction and put food waste (back) on to the political agenda.

Furthermore, already in 2011, the European Commission identified the food sector as key sector in its Roadmap to a Resource Efficient Europe [90]. The reduction of food waste and sustainable use of 
resources is also a targeted area of the EU action plan for the Circular Economy [91,92]. Within this context, in 2016, the EU Platform on Food Losses and Food Waste [93] was established. The platform brings together EU institutions and private actors and provides support in defining measures to prevent food waste, sharing best practice and evaluating progress [93-95]. More recently, as mentioned above, the European Commission addresses food waste as part of the Farm to Fork Strategy [4] and in its Communication of The European Green Deal [96].

\subsection{Amending Directive to the Waste Framework Directive}

Having discussed the relevant overarching targets, this section analyses the provisions of circular economy law of the EU regarding its integration of food waste. On 30 May 2018, the EU adopted Directive (EU) 2018/851 [97], which amends the Waste Framework Directive 2008/98/EG [98]. The new directive entered into force on 4 July 2018 and has to be transposed into national legislation by 5 July 2020. According to Article 9(1)(g) Directive (EU) 2018/851, Member States shall take measures to reduce the generation of food waste in primary production, in processing and manufacturing, in retail and other distribution of food, in restaurants and food services as well as in households as a contribution to SDG 12.3. While the proposal for a directive amending the Waste Framework Directive in 2014 included an objective to reduce food waste by 30 percent by 2025, the adopted amending directive does not include a quantified target for the reduction of food waste.

The amending directive also introduces a new Article 3(4a) which provides a definition of food waste (on definition issues see Section 3.2). Food waste means all food as defined in Article 2 of Regulation (EC) No 178/2002 [99] that has become waste. Furthermore, Member States shall monitor and assess the implementation of their food waste prevention measures by measuring the levels of food waste (Article 9 No. 5 Directive (EU) 2018/581).

In order to enhance the consistency and quality of food waste data, different initiatives, projects and instruments have been developed globally and in the EU. In 2016, a multi-stakeholder group (incl. UNEP and FUSIONS) published the Food Loss and Waste Accounting and Reporting Standard [100]. The standard aims to facilitate the quantification of food waste in providing a framework, e.g., uniform terminology, to all kinds of entities (businesses, NGOs, public authorities). Thus, rather than being a static structure, the standard is a flexible framework, which allows its users to choose the most appropriate scope for data generation [31,100]. Additionally, the FAO has developed two indices (Food Loss Index und Food Waste Index), which aim to track progress towards SDG Target 12.3. First results have been released in December 2019 [22,55]. In the EU, the European Commission initiated two research projects on food waste [8]: Food Use for Social Innovation by Optimising Waste Prevention Strategies (FUSIONS) (2012-2016) [101] and Resource Efficient Food and Drink for the Entire Supply Chain (REFRESH) (2015-2019) [102]. In addition to that, in May 2019, the European Commission adopted a delegated decision which establishes the scope and method for the measurement of food waste, voluntary measurements and minimum quality requirements. For example, Member States will be required to measure the amount of food waste for a given stage in the food supply chain applying a prescribed method at least once every four years (Article 2(2) Commission Delegated Decision (EU) 2019/1597) [95]. This policy entered into force in autumn 2019 and has the potential to enhance the consistency and quality of data that is generated in the EU and is thus considered a welcome step towards managing food waste issues (see Section 3.2). Data on food waste are expected to be available by 2022.

Apart from the introduction of the food waste definition and the rules for measuring food waste, the amending directive builds on the waste hierarchy of Directive 2008/98/EC. Since 2008, Article 4(1) Directive 2008/98/EC establishes a five-level hierarchy of waste which compromises-in descending order-the prevention, preparing for re-use, recycling, other recovery and disposal of waste. Thus, the prevention of (food) waste along the food supply chain obtains the highest priority. However, current legislative provisions do not establish a link to food waste which has led the European Court of Auditors to propose a waste hierarchy that is applied to food waste and thus takes into 
consideration the particularities of food. Ranging from most to least preferred, the proposed hierarchy consists of six levels starting with prevention, followed by donation, use as animal feed, recycling (e.g., for industrial uses), other recovery (e.g., for energy production) and disposal. The top three actions can be undertaken before food constitutes waste (based on the Ladder of Moerman, see [8] (p. 10)).

Article 9 Directive (EU) 2018/851 establishes provisions for the prevention of waste. According to Article 9(1) Member States shall take measures to prevent waste generation. Those measures shall, amongst others, promote and support sustainable production and consumption models (Article 9(1)(a)), reduce food waste as already discussed (Article 9(1)(g)) and encourage food donation and other redistribution for human consumption and thus prioritise human use over animal feed and the reprocessing into non-food products (Article 9(1)(h)). Annex IVa No. 3 directive (EU) 2018/851 lists fiscal incentives for donation of products and in particular food in accordance with the waste hierarchy. In addition to that, Member States shall also develop and support information campaigns to raise awareness about waste prevention and littering (Article 9(1)(m)) (critical on knowledge as motivational factor see Sections 2 and 3.4).

In addition to measures that address waste prevention, Member States are required to ensure that by 31 December 2023, biowaste is either separated and recycled at source, or is collected separately and is not mixed with other types of waste (Article 22 Directive (EU) 2018/851). This lays the foundation for further use of bio waste, e.g., for the use of compost as fertiliser. Article 11(2) No ii) Directive (EU) 2018/851 defines targets for the preparing for re-use and the recycling of municipal waste, which shall be increased to a minimum of 55 percent by weight by 2025 and 65 percent by 2035 . Member States shall furthermore establish waste prevention programs (Article 29(1) Directive (EU) 2018/851) as well as specific food waste prevention programs within their waste prevention programs (Article 29(2a) Directive (EU) 2018/851). Annex IV of Directive 2008/98/EC provides a list with examples of waste prevention measures. Yet, these do not include measures that address food waste prevention.

Altogether, the amended Waste Framework Directive and in particular Article 9(1) provides important starting points for the reduction of food waste and offers the Member States of the EU the legal framework to take effective measures to reduce food waste. In particular, the introduction of a food waste definition and the rules for measuring food waste are welcome steps towards tackling food wastage. Nevertheless, the fact that a legal link between food waste and the waste hierarchy and especially to the amended waste hierarchy for food products is missing, is regrettable from a food waste reduction perspective. Moreover, the current absence of a quantified, measurable and thus sanctionable reduction target for food waste in the amended Waste Framework Directive limits the steering effect of the legal framework on circular economy and waste. However, the proposal of the Farm to Fork Strategy (Action 26) to set a baseline for food waste based on the data on food waste expected from national capitals in 2022 is a first step to introduce legally binding reduction targets $[4,103]$. Notwithstanding that, the rather vague obligations of the directive stand in contrast with the urgent character of the underlying problem (see Section 3.1). Last but not least, the choice of instruments to be implemented by Member States remains open.

To reach a stronger governance effect of the circular economy and waste law on reducing food waste, a baseline and a clear, ambitious, measurable and sanctionable reduction target for food waste could be introduced for all Member States. In addition, a legal anchoring of the waste hierarchy taking into account the special character of food products and thus including in particular food donations (see Section 4.6) would be welcome.

\subsection{The Common Agricultural Policy and the Common Fisheries Policy}

This section discusses the provisions of the subsidy law of the agricultural sector of the EU as it is the central policy governing agricultural practices in the Member States. According to Article 39(1)(a) TFEU [104], one objective of the Common Agricultural Policy (CAP) is to increase agricultural productivity by ensuring the optimum utilisation of the production factors and thus requires an efficient use of resources. Resource efficiency is also incorporated in Article 11 TFEU which 
stipulates that environmental protection requirements have to be integrated into the Union's policies and activities.

As a comprehensive subsidy scheme, the CAP primarily provides direct income support for famers. These hectare-based payments have been made conditional on compliance with basic environmental requirements. Income support and market management measures form the first pillar of the CAP while the second pillar of the CAP focusses on rural development. Food waste has relevance for both pillars [8] (p. 27-31). Direct income support to farmers keeps consumer prices for food products at a (very) low level [105] which hinders the appreciation of food products and thus incentivises food waste (see Section 3.4; on food prices see Section 4.6). In contrast, support of the second pillar of the CAP can incentivise the reduction of food waste. Beneficial measures include investments in physical assets such as optimised storage facilities or improved stables to reduce animal mortality and diseases as well as information and co-operation (Annex IV of Regulation (EU) No 1305/2013) [106]. Member States are required to build their rural development programs (Pillar II) in line with six common EU priorities. These priorities include the promotion of resource efficiency in the agricultural and food sector (Article 5(5) Regulation (EU) No 1305/2013) by increasing efficiency in water use (Article 5(5)(a)) and in energy use in agriculture and food processing (Article 5(5)(b)) as well as by facilitating the supply and use of renewable sources of energy, of by-products, wastes and residues and of other non-food raw materials for the purposes of the bio-economy (Article 5(5)(c)). All these priorities clearly point towards food wastage reduction. Furthermore, Article 53(3)(c)(vii) Regulation (EU) No 1305/2013 provides that the European Innovation Partnership network shall facilitate the setting up of cluster initiatives and pilot or demonstration projects which may relate to the reduction of post-harvest losses and food wastage within the second pillar of the CAP. Still, making food waste reduction itself a priority for the rural development programs would set a clearer signal for Member States to develop measures to combat food waste [8] (p. 46-47). Thus far, the CAP does not integrate the food waste issue adequately and sets no sufficient incentives to reduce food waste.

As the CAP is currently undergoing a reform process (see [107-109] for the proposals for the European regulations; see [14] for a critical review), the question arises if the proposal for the future CAP provides more effective instruments to address food waste. The Commission has proposed that the CAP beyond 2020 will continue to consist of two pillars and the main instrument will, as presently, continue to be hectare-based payments. This is despite the fact that calls have been made to subject the CAP to a complete reorientation which provides support only for sustainable management practices which protect climate, biodiversity and soils, enhance resources efficiently and avoid wastage along the food supply chain. Interventions of the second pillar, which even presently struggle with underfunding, are expected to be affected more severely by proposed budget cuts [110] (p. 8). All this indicates that the future CAP neither will provide a sufficient framework to reduce food waste nor increase prices for resource intensive and environmental harmful food products and address the associated environmental issues.

Still, recent reforms of the CAP have had a positive impact on food waste by reducing overproduction. Fixed product prices and export refunds were replaced by coupled direct payments during the CAP reform in 1992 and by decoupled direct payments from 2005 onwards. As a consequence, surpluses and stockpiles of agricultural products including butter, skimmed milk powder, cereals and beef decreased significantly. Thus, moving from product to producer support probably contributed to a reduction of food waste [8] (p. 25) [62] (pp. 12, 13). However, the European Court of Auditors argues that this impact was coincidental rather than a result of targeted policy action [8] (pp. 7, 31). Furthermore the European Court of Auditors suggests that current coupled payments could stimulate production for products for which there may be no demand and thus promote the occurrence of food waste [8] (p. 27). Member States may currently provide coupled support to those sectors or to those regions where specific types of farming or specific agricultural sectors that are particularly important for economic, social or environmental reasons undergo certain difficulties (Article 52(3) Regulation (EU) No 1307/2013) [111]. In addition to that, market intervention 
measures which include market withdrawals, private storage, green or non-harvesting directly and indirectly contribute to food waste. Food products are removed from the market when prices are weak and stored until prices increase, or they are returned to the market for sale, donated or disposed of [8] (pp. 28, 29). Thus, market intervention measures should be reduced from the perspective of food waste avoidance.

Altogether, neither the present nor the future CAP are effective to reduce food waste. Rather than following the approach of 'public money for public goods' by increasing prices for environmental harmful and resource and greenhouse gas intensive products, subsidies support non-sustainable agricultural practices $[14,77,81,86,112]$ (p. 308). Thus, besides the reduction of the aforementioned market intervention measures and the integration of specific measures to reduce food waste into the new CAP regulations, increased prices for food products in accordance with their environmental impact would raise the appreciation of food and thus also stimulate the avoidance of food waste. This also implies an abolishment of environmental harmful subsidies [14,77,81,86,112,113]. Additionally, food waste could be an incorporated indicator in the fitness-check assessment of the CAP (for a CAP fitness-check see [86]).

In contrast to the $\mathrm{CAP}$, the $\mathrm{EU}$ has adopted measures to prevent food wastage within the Common Fisheries Policy (CFP). Since 2015, Article 15 Regulation (EU) No 1308/2013 [114] establishes that no edible fish shall be thrown back into the sea [92] (p. 15) [62] (pp. 12, 13). The full landing obligation entered into force in 2019 and requires that all catches shall be brought and retained on board the fishing vessels, recorded, landed and counted against the quotas where applicable. The landing obligation does not apply to, amongst others, species with high survival rates after being thrown back into the sea. Projects which facilitate the implementation of the landing obligation can be funded through the European Fisheries Fund (EFF) and the European Maritime and Fisheries Fund (EMFF). This may include investments in selective fishing gear and equipment for dealing with unwanted catches on board. Thus, the landing obligation has the potential to reduce food waste if correctly implemented, i.e., if it leads to increased selectivity and thus less unwanted by-catch. At the same time, the landing obligation itself does not prevent that all edible fish that cannot be used for human consumption (e.g., due to minimum size requirements) turns into food waste [8] (pp. 33, 34). Hence, there is still room for improvement, for example with regard to improved selectivity and the use of non-marketable fish for further processing, in canteens or as donations (see Section 4.6).

\subsection{Food Safety, Packaging, Norms and Date Labelling}

Food safety and hygiene provisions for producers, processors and retailers ensure that food products are safe for consumption. Nevertheless, a critical analysis of these rules can indicate whether they contribute to food waste by being outdated, too unspecific or by exceeding essential requirements of food safety. Furthermore, recalls and withdrawals for food safety reasons have to be targeted and accurate. Traceability of food products provides the foundation for differentiated recalls and withdrawals.

Regulation (EC) No 178/2002 [99] establishes that a food or feed business can identify at least the business from which the food has been supplied to ensure that traceability can be assured at all stages of the food supply chain. Directive 2011/91/EU [115] establishes the legal provisions for indications or marks which identify the lot to which a foodstuff belongs. The more refined a traceability system, the less food is wasted during a recall or withdrawal. However, the directive does not establish rules on the size of the lots and instead leaves this design feature up to the discretion of the Member States [8] (pp. 36, 37). A more effective governance approach would require Member States to adopt very small lot sizes based on the date of production and thereby enable highly targeted recalls or withdrawals.

Another dimension of food safety and hygiene is food packaging. Food packaging can also increase the shelf-life of food products such as fruit and vegetables and thus reduce food waste [116] (p. 12). However, this may conflict with environment and resource objectives which call for a reduction 
of packaging waste and especially plastic waste $[13,117]$. Therefore, other measures to reduce food waste should be adopted preferably. At the same time, food packaging that is unavoidable to ensure the safety of food products should be plastic-free, biodegradable and reusable [4].

European legislation furthermore contains specific marketing standards for fruit and vegetables. In contrast to the provisions above, these standards are required for aesthetic rather than food safety purposes and thus cause food waste for imperfect shapes or appearances [62] (pp. 1, 12) [118] (p. 116). In 2011, marketing standards for 26 fruit and vegetable products were abolished. However, it seems that this move has not contributed to a reduction of food waste because actors along the food supply chain continue to require-partly even stricter—standards [119] (p. 28) [8] (pp. 48-50) [62] (p. 12). In order to reduce food waste, these requirements should be abolished and at the same time incentives provided to use food products which deviate from (legal) norm range in e.g., restaurants and canteens.

For food safety reasons instead, food products are labelled with dates. However, as discussed in Section 3.4, food labelling frequently contributes to confusion about the safety of food products. As a consequence, safe and edible food is thrown away. The European Commission acknowledges this issues and in particular the wrong interpretation of the 'best before' date and has included it into the action plan for the Circular Economy [92] (p. 18) [4] (p. 15). The provisions of food information to consumers are established in Regulation (EU) No 1169/2011 [120]. According to Article 9(1)(f) Regulation (EU) No 1169/2011, the date of minimum durability or the 'use by' date are mandatory food information. Article 2(2)(r) Regulation (EU) No 1169/2011 lays down that the date of minimum durability means the date until which the food retains its specific properties when properly stored. It shall be replaced by the 'use by' date in the case of foods which are highly perishable and are therefore likely after a short period to constitute an immediate danger to human health. After the 'use by' date, a food shall be deemed to be unsafe according to Article 24(1) Regulation (EU) No 1169/2011. In contrast, food may still be acceptable for consumption beyond the minimum durability date and can, according to EU provisions, still be sold after that date. However, national legislation in some Member States prohibits to sell food products after the minimum durability date und thereby increases food wastage at the retail level [8] (pp. 37, 38). This is mirrored in the study results regarding reasons of food waste along the food supply chain (see Section 3.4). It is questionable whether some products require a minimum durability date at all, and if so, whether this date is not indicated too short. For example, salt and herbs can be stored for long periods and thus do not require a minimum durability date. In fact, cooking salt is among the few food products which do not need a minimum durability date in accordance with Annex X Regulation (EU) No 1169/2011. Unless the minimum durability date is not abolished, an extension of this list would be desirable from the perspective of food waste reduction. Furthermore, uniform provisions of date labelling of food products among the Member States could reduce food waste. The Commission has announced an examination of present provisions of food labelling in its action plan for the Circular Economy [91] (p. 6) [92] (p. 18).

\subsection{Dumpster Diving, Disposal Bans and Foodsharing}

This section assesses different measures which have an impact of food waste at the retail and consumption level. Retailers could sell food products which are close or beyond the minimum durability date at lower prices or give them away for free [116] (p. 13) [121]. A counterproductive development affects dumpster diving in Germany, i.e., taking food from the waste containers of supermarkets or factories. A recent judgment of the German Bayerisches Oberstes Landesgericht [122] upheld a local court's verdict that dumpster diving is illegal. Rather than putting food products to be disposed of in locked waste containers, which will be picked up by waste disposal companies, they could be made available for charities or private persons and thereby reduce food waste. Furthermore, measures which prohibit the wastage of food like in France could be adopted. Since 2016, supermarkets in France are obligated to sign agreements with charities to donate food that would otherwise be thrown away [8] (p. 22) [123]. Yet, a petition to the German Bundestag calling for a ban on the disposal of food has so far been unanswered $[124,125]$ and attempts to legalise dumpster diving were unsuccessful 
by now. Until now, it remains to be seen if the German Federal Constitutional Court will deal with this topic.

Incentives to share non-needed food do nearly not exist at the household level—despite the fact that this stage accounts for the largest share of all food wasted (see Section 3.4). While there are a few foodsharing initiatives that support the sharing and passing on of food products at the retail level and the household level, they operate in niches (e.g., [126-128]). In addition to banning the practice of throwing away edible food that is no longer intended for sale and instead offering it to individuals or (charity) organisations, food sharing initiatives and further initiatives from civil society and enterprises/industry could also be given more support by the state in order to reduce the wastage of edible food, as these initiatives are suitable to support legal measures (e.g., for Denmark's civil society-driven anti-waste framework see [27] (pp. 246-265), for food banks see Section 4.6).

\section{6. (Fiscal) Incentives for Food Donations}

At last, tax law can have implications for food waste by e.g., providing incentives for food donations. According to the action plan for the Circular Economy, the Commission will take measures on the rules concerning food donations to food banks and the use of safe yet unsold food products as animal feed [91] (p. 6) [92] (p. 17). Yet, currently, there is a number of barriers to food donation in EU legislation. This includes for example the waste hierarchy of the Waste Framework Directive which has not been adapted to the specifies of food (see Section 4.2) and unclarities regarding whether food banks and charities are to be considered as 'food business operators' and thus have to comply with the provisions of food law (Regulation (EC) No 178/2002). Here, a clarification on European level may be desirable to make food donations more attractive and to reduce food waste. A good example is the Italy, which implemented a national law on food (and pharmaceutical) products donation in 2016 [129]. In addition to providing definitions for important terms such as food operators, donators, food leftover and food waste, expiration date and best before date, the Italian law establishes incentives for free food leftover to charity organisations, e.g., by supermarkets or farmers. In fact, the law allows municipalities to establish tax exemptions for food donators. In addition, initiatives aiming at avoiding food waste are supported financially by a new fund. Additionally, these measures are supported by e.g., informational measures such as awareness campaigns and educational programs for schools $[9,123]$.

In addition to that, the provisions of the existing legal framework are not sufficiently exploited. This includes provisions of the Fund for European Aid to the Most Deprived where Member States have the possibility to donate food products which have been taken out of the market in the context of CAP market measures (Regulation (EU) No 1308/2013 and Article 4(1) Regulation (EU) No 223/2014 [130]), e.g., by funding food banks. Other areas entirely lack legal provisions for food donations. For example, the CFP does not provide any framework that encourages the donation of non-marketable fish [8] (p. 41). In order to reduce food waste, existing legal provisions should be further clarified and exploited, and measures in policy areas which currently do not provide rules on food donations developed. An obligation to donate food at the retail level as adopted in France would also be conceivable [8] (p. 22).

As mentioned above, using the example of Italy, fiscal incentives for food donations are considered to be an effective mechanism to encourage food donations and reduce food waste. Yet, there are unclarities on how the value added tax is to be applied on donated food. While the value added tax system of the EU (in particular Article 16 Council Directive No 2006/112/EC [131]) does not constitute a barrier to food donations in general, the national interpretation of some Member States of this Directive hinders food donations [8] (p. 40) [132]. The Directive establishes that the value added tax has to be applied on donated food. Member States can choose to set a tax rate close to zero if the product is close to the minimum durability date or when products are not fit for sale. However, the term 'fit for sale' has not been further specified and can thus be interpreted in different ways. This legal uncertainty can hinder the donation of food products and should be addressed soon [8] (p. 41). 


\section{Discussion: Shortcomings of Existing Law and Recommendations for Improvement-Economic Instruments as Alternative}

Despite repeated political statements and initiatives, there is currently no coherent and ambitious approach to tackle food waste along the entire food supply chain in the EU [8] (p. 7). It was shown that the analysed areas of law with relevance for food waste (i.e., circular economy and waste law, the CAP and CFP, the law of food safety and packaging, norms and date labelling as well as the relevant law for food disposal, foodsharing and food donations) include some important starting points to tackle food wastage in the EU. Yet, the analysis also finds that these areas of law lack an adequate steering effect to significantly reduce food waste as required by international environmental targets. Before this background, some moderate and pragmatic proposals for improvement have been made for the specific areas of legislation, which are summarised in Figure 1. They include an ambitious, measurable and sanctionable reduction target for food waste within the framework of the circular economy and waste law and the integration of specific measures to reduce food waste into the new $\mathrm{CAP}$ regulations. Furthermore, it was proposed to remove barriers to reduce food waste such as legal and private norms; to harmonise relevant regulations of Member States such as date labelling as well as to provide (fiscal) incentives to promote food donations.

All of these proposals are detailed recommendations that foster food waste reduction in the various areas of agricultural and food law. However, given the extent and urgency of the environmental problems of the agricultural sector, which are directly related to the wastage of food (see Sections 1 and 3.1), it is not sufficient to slightly reduce food waste in some sub-areas of the food supply chain (e.g., food donations at retail or household level). In addition to that, the global environmental targets require a drastic reduction of food waste in all sectors if they are to be achieved (see Sections 3.1 and 4.1). However, the regulatory law in particular suffers from governance problems as described in Section 2: The effect of the detailed law, which focuses on individual products or processes, is limited by rebound effects, spatial and sectoral shifting effects, lack of rigour as well as problems of depicting and enforcement. Therefore, the effects of the discussed optimising regulatory options would be limited. At the same time, informational instruments such as eco-labels, voluntary measures or nudging measures to incentivise consumers to avoid food waste can be supportive (see e.g., [133] (pp. 72-74) [134] (pp. 35-42) [135] (pp. 58-59) [9] (pp. 6,7)) but are not sufficient to meet the urgent ecological challenges such as climate change and biodiversity loss (see Sections 1, 3.1 and 4.1). Instead, comprehensive quantity control instruments are suitable instruments for integrative solutions of manifold environmental problems. In contrast to command-and-control approaches targeting individual fields such as food packaging or food donations, these instruments allow to set overarching, strong incentives for more environmental sound behaviour in line with the Paris Agreement and the Convention on Biological Diversity.

As food waste is an issue that occurs across multiple sectors and levels and is related to multifactorial motivations (Sections 2 and 3), it could be well addressed through economic instruments which have already been found to be effective in reducing, amongst others, fossil fuels and animal-derived products [11,16]. Rather than directly changing behaviour through command-and-control law, economic instruments such as taxes and cap-and-trade systems change behaviour indirectly by increasing prices for consumers and simultaneously trigger higher efficiency in earlier steps of the food supply chain. If economic instruments address easily measurable governance units such as fossil fuels and livestock products, they do not require detailed information and face lower depicting and enforcement problems $[11,12,16,77]$. Established on a broad geographical scale and across all sectors, they furthermore prevent issues of depicting and spatial and sectoral shifting effects-all of which arise with command-and-control approaches. Absolute quantity limitations which can be achieved through a cap-and-trade system furthermore avoid rebound effects $[11,16]$. At the same time, prices address multiple motivational factors of actors (consumers, farmers, etc.) including self-interest and conceptions of normality. Prices furthermore stimulate the interest in more factual knowledge and disturb problematic emotional factors such as convenience and denial $[16,19,20]$ 
(see Sections 2 and 3.4). Economic instruments trigger activities for emission avoidance and environmental improvement at comparatively low costs and leave the path towards an environmental target up to the individual (e.g., paying a tax, buying a certificate or undertake measures for environmental protection) which is why they are regarded as freedom-oriented instruments [16,77].

Waste Governance.JPG

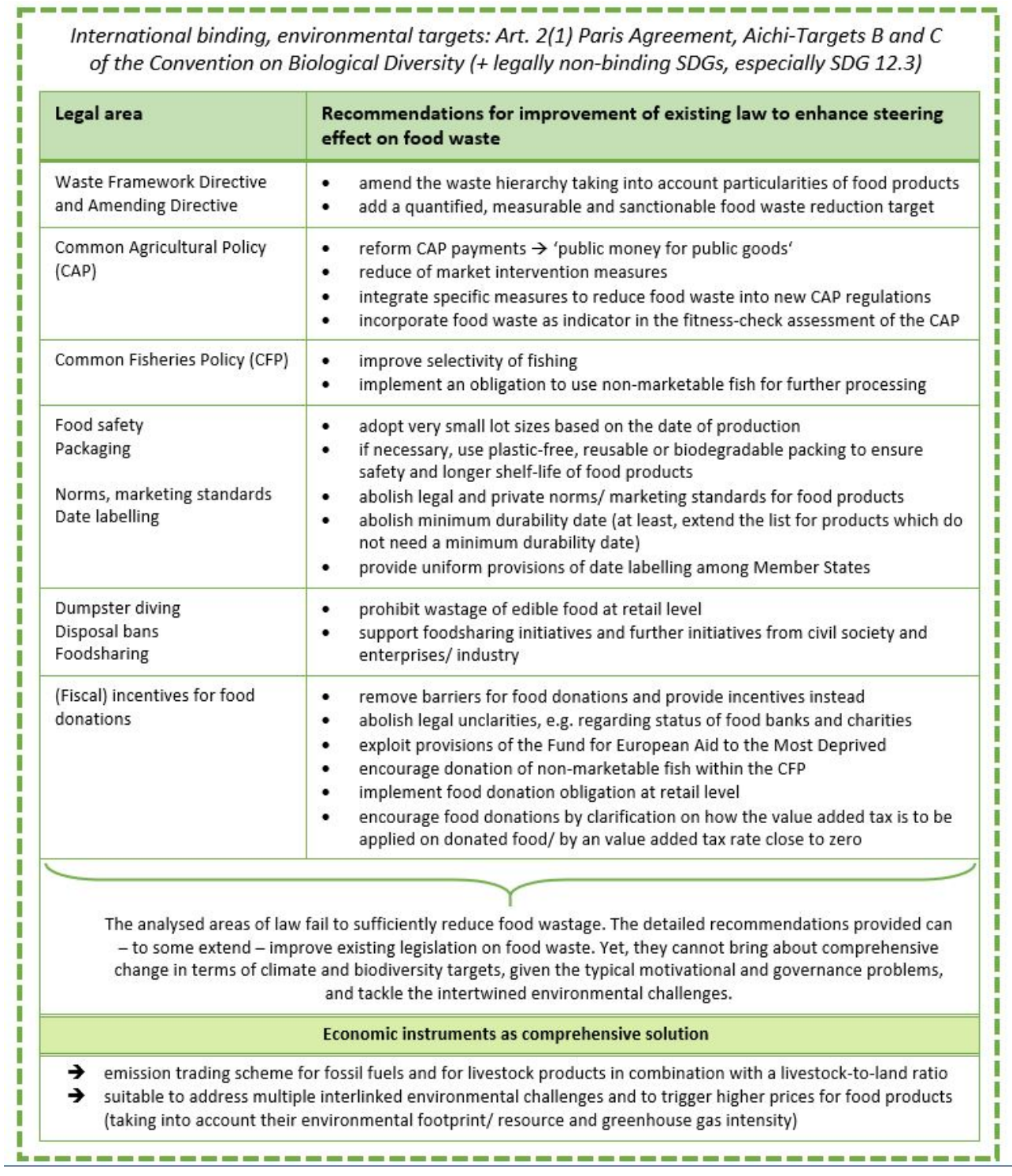

Figure 1. Recommendations for improvement of existing law and economic instruments as alternative to tackle food waste.

In theory, one approach to address the issue of food waste could also be to directly increase prices for the waste through a high tax rate. However, given the largest share of food waste occurs at the household level and because of the fact that food waste occurs at each step along the food supply chain (see Section 3.3), a regulatory authority will face substantial administrative burdens in controlling and enforcing such a tax. Instead, a more comprehensive landfill tax, as (re-)introduced in the Netherlands in 2015, seems to be at least a more promising response. The tax accounts for 17 Euros per ton and landfilling of municipal and recyclable waste has been banned [116] (p. 7). As a result that this tax does not explicitly target food waste, food waste does not have to be quantified for the collection of taxes. Yet, it seems unlikely that a land-filling tax can effectively address food 
waste along the entire food supply chain especially because it incentivises recycling rather than the prevention of food waste.

Higher food prices (in particular for resource intensive and environmental harmful products) can induce a contribution to the reduction of food waste-especially at the household level [136] (p. 11). Instead of undertaking punctual changes in the CAP, as they are established in recent proposals for the future CAP regulations (see Section 4.3), a EU primary energy emission trading system with a cap aligned with Article 2(1) Paris Agreement in combination with an emission trading system for livestock products and a livestock-to-land ratio is suitable to address multiple interlinked environmental issues $[11,16,77]$. The pricing of fossil fuels increases food prices, especially for ecologically harmful food, but price increases are also likely for less ecologically harmful products. Therefore, such pricing have to be accompanied by an increase of the basic social security. The ecological effectiveness of the system is not affected by this, because cap-and-trade schemes still reach the defined quantity limit. Additionally, such an approach would probably require a collaboration with further countries and a complementary border adjustment for imports and exports of countries which do not have comparable provisions in place. Indeed, border adjustments have recently been put on the agenda of the European Commission within the framework of the European Green Deal [96].

Increasing prices especially for animal-derived products would not only provide an incentive for less consumption of such products and different production methods but also avoid food waste of products with a particularly high environmental and resource footprint. At the same time, fossil fuels play a key role in almost all areas of life and the economy-including the agricultural sector-and a strict cap that removes fossil fuels within no more than two decades from the market, would also lead to higher production costs in the agricultural sector $[16,46,79,137,138]$. As a consequence, food prices would rise and thereby stimulate efficiency, consistency and frugality and also avoid food waste. This would not only contribute to the fulfilment of SDG 12.3 'halving per capita global food waste', but also to SDG 2 'end hunger' and further social and environmental SDGs.

Author Contributions: Conceptualisation: B.G., K.H., F.E.; methodology: F.E.; formal analysis: B.G. and K.H.; investigation: B.G., K.H., L.M.W., W.G.; writing—original draft preparation: K.H. and B.G.; writing一review and editing: B.G., K.H. and F.E.; supervision: F.E. All authors have read and agreed to the published version of the manuscript.

Funding: This research was partly funded by the German Federal Ministry of Education and Research (BMBF) within the BonaRes project InnoSoilPhos (No. 031B0509) and by the Leibniz Association within the framework of the Leibniz ScienceCampus Phosphorus Research Rostock.

Acknowledgments: The authors gratefully acknowledge the German Federal Ministry of Education and Research (BMBF) for funding the BonaRes project InnoSoilPhos (No. 031B0509) and the Leibniz Association for funding the Leibniz ScienceCampus Phosphorus Research Rostock.

Conflicts of Interest: The authors declare no conflict of interest.

\section{References}

1. Kummu, M.; de Moel, H.; Porkka, M.; Siebert, S.; Varis, O.; Ward, P.J. Lost food, wasted resources: Global food supply chain losses and their impacts on freshwater, cropland, and fertiliser use. Sci. Total Environ. 2012, 438, 477-489. [CrossRef] [PubMed]

2. Intergovernmental Science-Policy Platform on Biodiversity and Ecosystem Services (IPBES). Summary for Policymakers of the Global Assessment Report on Biodiversity and Ecosystem Services; IPBES Secretariat: Bonn, Germany, 2019.

3. Intergovernmental Panel on Climate Change (IPCC). Climate Change and Land. An IPCC Special Report on Climate Change, Desertification, Land Degradation, Sustainable Land Management, Food Security, and Greenhouse Gas Fluxes in Terrestrial Ecosystems; Summary for Policymakers; IPCC Secretariat: Geneva, Switzerland, 2020.

4. European Commission. Communication from the Commission to the European Parliament, the Council, the European Economic and Social Committee and the Committee of the Regions: A Farm to Fork Strategy for a Fair, Healthy and Environmentally-Friendly Food System; COM(2020) 381 Final from 20.05.2020; European Commission: Brussels, Belgium, 2020. 
5. Stenmarck, Å.; Jensen, C.; Quested, T.; Moates, G.; Buksti, M.; Cseh, B.; Juul, S.; Parry, A.; Politano, A.; Redlingshofer, B.; et al. FUSIONS. Estimates of European Food Waste Levels; IVL Swedish Environmental Research Institute: Stockholm, Sweden, 2016.

6. EUROSTAT. Obesity Rate by Body Mass Index (BMI). Online Data Code: SDG_02_10. Available online: https: / / ec.europa.eu/eurostat/databrowser/view/sdg_02_10/default/table?lang=en (accessed on 23 June 2020).

7. United Nations (UN). A/RES/70/1, Resolution adopted by the General Assembly on 25.09.2015. Transforming our World: The 2030 Agenda for Sustainable Development; United Nations: New York, NY, USA, 2015.

8. European Court of Auditors (ECA). Combating Food Waste: An Opportunity for the EU to Improve the Resource-Efficiency of the Food Supply Chain; Special Report No. 34/2016; European Court of Auditors: Luxembourg, 2016.

9. Vittuari, M.; Politano, A.; Gaiani, S.; Canali, M.; Elander, M. Review of EU Member States Legislation and Policies with Implications on Food Waste. FUSIONS; Final Report; University of Bologna: Bologna, Italy, 2015.

10. EUR-Lex. Access to European Union Law. Available online: https:/ / eur-lex.europa.eu/ (accessed on 7 July 2020).

11. Weishaupt, A.; Ekardt, F; Garske, B.; Stubenrauch, J.; Wieding, J. Land Use, Livestock, Quantity Governance, and Economic Instruments—Sustainability Beyond Big Livestock Herds and Fossil Fuels. Sustainability 2020, 12, 2053. [CrossRef]

12. Ekardt, F.; Jacobs, B.; Stubenrauch, J.; Garske, B. Peatland Governance: The Problem of Depicting in Sustainability Governance, Regulatory Law, and Economic Instruments. Land 2020, 9, 83. [CrossRef]

13. Stubenrauch, J.; Ekardt, F. Plastic Pollution in Soils: Governance Apporaches to Foster Soil Health and Closed Nutrient Cycles. Environments 2020, 7, 38. [CrossRef]

14. Heyl, K.; Döring, T.; Garske, B.; Stubenrauch, J.; Ekardt, F. The Common Agricultural Policy beyond 2020: A critical Review. Rev. Eur. Comp. Int. Environ. Law 2020, 1-12. [CrossRef]

15. Garske, B.; Stubenrauch, J.; Ekardt, F. Sustainable phosphorus management in European agricultural and environmental law. Rev. Eur. Comp. Int. Environ. Law 2020, 29, 1-11. [CrossRef]

16. Ekardt, F. Sustainability: Transformation, Governance, Ethics, Law; Springer Nature: Dordrecht, The Netherlands, 2019.

17. United Nations (UN). Paris Agreement; FCCC/CP/2015/L.9/Rev.1; United Nations: New York, NY, USA, 2015.

18. United Nations (UN). Convention on Biological Diversity; 1760 UNTS 79; 31 ILM 818 (1992); United Nations: New York, NY, USA, 1992.

19. Stoll-Kleemann, S.; Schmidt, U.J. Reducing meat consumption in developed and transition countries to counter climate change and biodiversity loss: A review of influence factors. Reg. Environ. Chang. 2017, 17, 1261-1277. [CrossRef]

20. Stoll-Kleemann, S.; O'Riordan, T. Revisiting the Psychology of Denial Concerning Low-Carbon Behaviors: From Moral Disengangement to Generating Social Change. Sustainability 2020, 12, 935. [CrossRef]

21. European Parliament. Resolution of 19 January 2012 on How to Avoid Food Wastage: Strategies for a More Efficient Food Chain in the EU (2011/2175(INI)); OJ 2013/C 227 E/05; European Parliament: Strasbourg, France, 2012.

22. Food and Agriculture Organization of the United Nations (FAO). The State of Food and Agriculture 2019. Moving Forward on Food Loss and Waste Reduction; FAO: Rome, Italy, 2019.

23. Chaboud, G.; Daviron, B. Food losses and waste: Navigating the inconsistencies. Glob. Food Secur. 2017, 12, 1-7. [CrossRef]

24. Food and Agriculture Organization of the United Nations (FAO). Food Wastage Footprint: Impacts on Natural Resources; Summary Report; FAO: Rome, Italy, 2013.

25. Östergren, K.; Gustavsson, J.; Bas-Brouwers, H.; Timmermans, T.; Hansen, O.-J.; Møller, H.; Anderson, G.; O'Connor, C.; Soethoudt, H.; Quested, T.; et al. FUSIONS Definitional Framework for Food Waste; Full Report; The Swedish Institute for Food and Biotechnology: Göteborg, Sweden, 2014.

26. Scherhaufer, S.; Moates, G.; Hartikainen, H.; Waldron, K.; Obersteiner, G. Environmental impacts of food waste in Europe. Waste Manag. 2018, 77, 98-113. [CrossRef] [PubMed]

27. Szulecka, J.; Strøm-Andersen, N.; Scordato, L.; Skrivervik, E. Multi-level governance of food waste. Comparing Norway, Denmark and Sweden. In From Waste to Value. Valorisation Pathways for Organic Waste Streams in Circular Bioeconomics; Klitkou, A., Fevolden, A.M., Capasso, M., Eds.; Tayler \& Francis: London, UK, 2019; pp. 253-271.

28. Bajželj, B.; Richards, K.S.; Allwood, J.M.; Smith, P.; Dennis, J.S.; Curmi, E.; Gilligan, C.A. Importance of food-demand management for climate mitigation. Nat. Clim. Chang. 2014, 4, 924-929. [CrossRef] 
29. Johnson, J.A.; Runge, C.F.; Senauer, B.; Foley, J.; Polasky, S. Global agriculture and carbon trade-offs. Proc. Natl. Acad. Sci. USA 2014, 111, 12342-12347. [CrossRef] [PubMed]

30. Ordway, E.M.; Asner, G.P.; Labin, E. Deforestration risk due to commodity crop expansion in sub-Saharan Africa. Environ. Res. Lett. 2017, 12, 1-14. [CrossRef]

31. Gillik, S.; Quested, T. Houshold food waste: Restated Data for 2007-2015; Final Report; WRAP: Banbury, UK, 2018.

32. Vanham, D.; Bouraoui, F.; Leip, A.; Grizzetti, B.; Bidoglio, G. Lost water and nitrogen resources due to EU consumer food waste. Environ. Res. Lett. 2015, 10,1-16. [CrossRef]

33. Intergovernmental Science-Policy Platform on Biodiversity and Ecosystem Services (IPBES). The Assessment Report on Land Degradation and Restoration; IPBES Secretariat: Bonn, Germany, 2018.

34. Leinweber, P.; Bathmann, U.; Buczko, U.; Douhaire, C.; Eichler-Löbermann, B.; Frossard, E.; Ekardt, F.; Jarvie, H.; Krämer, I.; Kabbe, C.; et al. Handling the phosphorus paradox in agriculture and natural ecosystems: Scarcity, necessity, and burden of P. Ambio 2018, 47 (Suppl. 1), 3-19. [CrossRef] [PubMed]

35. International Panel of Experts on Sustainable Food Systems (iPES Food). From Uniformity to Diversity: A Paradigm Shift from Industrial Agriculture to Diversified Agroecological Systems; iPES Food: Brussels, Belgium, 2016.

36. Stubenrauch, J.; Garske, B.; Ekardt, F. Sustainable Land Use, Soil Protection and Phosphorus Management from a Cross-National Perspective. Sustainability 2018, 10, 1988. [CrossRef]

37. European Commission. Communication from the Commission to the European Parliament, the Council, the European Economic and Social Committee and the Committee of the Regions: On the Review of the List of Critical Raw Materials for the EU and the Implementation of the Raw Materials Initiative; COM(2014) 297 Final from 26.05.2014; European Commission: Brussels, Belgium, 2014.

38. Sutton, M.A.; Bleeker, A.; Howard, C.M.; Erisman, J.W.; Abrol, Y.P.; Bekunda, M.; Datta, A.; Davidson, E.; De Vries, W.; Oenema, O.; et al. Our Nutrient World. The Challenge to Produce More Food and Energy with Less Pollution. Global Overview of Nutrient Management; Centre for Ecology and Hydrology: Edinburgh, UK, 2013.

39. Food and Agriculture Organization of the United Nations (FAO). Food Wastage Footprint E Climate Change; FAO: Rome, Italy, 2017.

40. Porter, S.D.; Reay, D.S.; Higgins, P.; Bomberg, E. A half-century of production-phase greenhouse gas emissions from food loss \& waste in the global food supply chain. Sci. Total Environ. 2016, 571, 721-729.

41. Venkat, K. The climate Change and Economic Impacts of Food Waste in the United States. Int. J. Food Syst. Dyn. 2011, 2, 431-446.

42. Zhang, C.; Su, H.; Baeyens, J.; Tan, T. Reviewing the anaerobic digestion of food waste for biogas production. Renew. Sustain. Energy Rev. 2014, 38, 383-392. [CrossRef]

43. Adhikari, B.K.; Barrington, S.; Martinez, J. Predicted growth of world urban food waste and methane production. Waste Manag. Res. 2006, 24, 421-433. [CrossRef]

44. Monier, V.; Mudgal, S.; Escalon, V.; O'Connor, C.; Gibon, T.; Anderson, G.; Montoux, H.; Reisinger, H.; Dolley, P.; Ogilvie, S.; et al. Preparatory Study on Food Waste Across EU 27; Final Report; European Commission (DG ENV): Brussels, Belgium, 2010.

45. Garnett, T. Where are the best opportunities for reducing greenhouse gas emissions in the food system (including the food chain)? Food Policy 2011, 36 (Suppl. 1), S23-S32. [CrossRef]

46. Intergovernmental Panel on Climate Change (IPCC). Global Warming of $1.5^{\circ} \mathrm{C}$ : An IPCC Special Report on the Impacts of Global Warming of $1.5^{\circ} \mathrm{C}$ above Pre-Industrial Levels and Related Global Greenhouse gas Emission Pathways, in the Context of Strengthening the Global Response to the Threat of Climate Change, Sustainable Development, and Efforts to Eradicate Poverty; IPCC Secretariat: Geneva, Switzerland, 2018.

47. Springmann, M.; Clark, M.; Mason-D'Croz, D.; Wiebe, K.; Bodirsky, B.L.; Lassaletta, L.; De Vries, W.; Vermeulen, S.J.; Herrero, M.; Carlson, K.M.; et al. Option for Keeping the food system within environmental limits. Nature 2018, 562, 519-525. [CrossRef] [PubMed]

48. Parfitt, J.; Barthel, M.; Macnaughton, S. Food waste within food supply chains: Quantification and potential for change to 2050. Philos. Trans. R. Soc. Biol. Sci. 2010, 365, 3065-3081. [CrossRef] [PubMed]

49. Food and Agriculture Organization of the United Nations (FAO). Global Food Losses and Food Waste. Extent, Causes and Prevention; FAO: Rome, Italy, 2011.

50. Hafner, G.; Barabosz, J.; Leverenz, D.; Maurer, C.; Kranert, M.; Göbel, C.; Friedrich, S.; Ritter, G.; Teitscheid, P.; Wetter, C. Analysis, Evaluation and Optimization of Food Management. Part I: Definition of "Food Loss" and "Food Waste". Müll und Abfall 2013, 11, 601-609. 
51. Thyberg, K.L.; Tonjes, D.J. Drivers of food waste and their implications for sustainable policy development. Resour. Conserv. Recycl. 2016, 106, 110-123. [CrossRef]

52. Garcia-Garcia G.; Wooley, E.; Rahimifard, S. A Framework for a More Efficient Approach to Food Waste Management. Int. J. Food Eng. 2015, 1, 65-72. [CrossRef]

53. European Commission. Commission Delegated Decission (EU) .../... Supplementing Directive 2008/98/EC of the European Parliament and of the Concil as Regards a Common Methododolgy and Minimum Quality Requirements of the Uniform Measurement of Levels of Food Waste; C/2019/3211 Final from 03.05.2019; European Commission: Brussels, Belgium, 2019.

54. Caldeira, C.; De Laurentiis, V.; Corrado, S.; van Holsteijn, F.; Sala, S. Quantification of food waste per product group along the supply chain in the European Union: A mass flow analysis. Resour. Conserv. Recycl. 2019, 149, 479-488. [CrossRef]

55. Food and Agriculture Organization of the United Nations (FAO). Methodological proposal for monitoring SDG target 12.3.1. sub-indicator 12.3.1.A. The Food Loss Index Design, Data Collection Methods and Challenges; FAO Statistics Working Paper Series 18-13; FAO: Rome, Italy, 2019.

56. Quested, T.; Johnson, H. Household Food and Drink Waste in the UK; Final Report; WRAP: Banburry, UK, 2009.

57. Alexander, P.; Brown, C.; Arneth, A.; Finnigan, J.; Moran, D.; Rounsevell, M.D.A. Losses, inefficiencies and waste in the global food system. Agric. Syst. 2017, 153, 190-200. [CrossRef]

58. Smil, V. Improving Efficiency and Reducing Waste in Our food System. Environ. Sci. 2004, 1, 17-26. [CrossRef]

59. Bellemare, M.F; Çakir, M.; Peterson, H.H. On the Measurement of Food Waste. Am. J. Agric. Econ. 2017, 99, $1148-1158$. [CrossRef]

60. Bräutigam, K.R.; Jörissen, J.; Priefer, C. The extend of food waste generation across EU-27: Different calculation methods and the reliability of their results. Waste Manag. Res. 2014, 32, 683-694. [CrossRef] [PubMed]

61. Xue, L.; Liu, G.; Parfitt, J.; Liu, X.; Van Herpen, E.; Stenmarck, Å.; O’Connor, C.; Östergren, K.; Cheng, S. Missing Food, Missing Data? A Critical Review of Global Food Losses and Food Waste Data. Environ. Sci. Technol. 2017, 51, 6618-6633. [CrossRef] [PubMed]

62. Canali, M.; Amani, P.; Aramyan, L.; Gheoldus, M.; Moates, G.; Östergren, K.; Silvennoinen, K.; Waldron, K.; Vittuari, M. Food Waste Drivers in Europe, from Identification to Possible Interventions. Sustainability 2017, 9, 37. [CrossRef]

63. Food and Agriculture Organization of the United Nations (FAO); International Fund for Agricultural Development (IFAD); United Nations Children's Fund (UNICEF); World Food Programme (WFP); World Health Organization (WHO). The State of Food Security and Nutrition in the World 2019: Safeguarding Against Economic Slowdowns and Downturns; FAO: Rome, Italy, 2019.

64. Inner City Fund (ICF). Market Study on Date Marking and Other Information Provided on Food Labels and Food Waste Prevention; European Commission: Brussels, Belgium, 2018.

65. Van Geffen, L.; van Herpen, E.; van Trijp, H. Household Food Waste-How to Avoid it? An Integrative Review. In Food Waste Management. Solving the Wicket Problem; Närvänen, E., Mesiranta, N., Mattila, M., Heikkinen, A., Eds.; Palgrave Macmillan: London, UK, 2020; pp. 27-55.

66. High Level Panel of Experts on Food Security and Nutrition (HLPE). Food losses and waste in the context of sustainable food systems. A Report by the High Level Panel of Experts on Food Security and Nutrition of the Committee on World Food Security; FAO: Rome, Italy, 2014.

67. Koivupuro, H.-K.; Hartikainen, H.; Silvennoinen, K.; Katajajuuri, J.-M.; Heikintalo, N.; Reinikainen, A.; Jalkanen, L. Influence of socio-demographical, behavioural and attitudinal factors on the amount of avoidable food waste generated in Finnish households. Int. J. Consum. Stud. 2012, 36, 183-191. [CrossRef]

68. Mena, C.; Adenso-Diaz, B.; Yurt, O. The causes of food waste in the supplier-retailer inferface: Evidences from the UK and Spain. Resour. Conserv. Recycl. 2011, 55, 648-658. [CrossRef]

69. Hall-Philipps, A.; Shah, P. Unclarity confusion and expiration date labels in the United States: A consumer perspective. J. Retail. Consum. Serv. 2017, 35, 118-126. [CrossRef]

70. Schmidt, T.; Schneider, F.; Leverenz, D.; Hafner, G. Lebensmittelabfälle in Deutschland_Baseline 2015; Johann Heinrich von Thünen-Institut: Brunswick, Germany, 2015.

71. Quested, T.; Marsh, E.; Stunnel, D.; Parry, A.D. Spaghetti soup: The complex world of food waste behaviours. Res. Conserv. Recycl. 2013, 79, 43-51. [CrossRef] 
72. Hebrok, M.; Boks, C. Houshold food waste: Drivers and potential intervention points for design-An extensive review. J. Clean. Prod. 2017, 151, 380-392. [CrossRef]

73. Evans, D. Blaming the Consumer-Once Again: The social and material contexts of everyday food waste practices in some English households. Crit. Public Health 2011, 21, 429-440. [CrossRef]

74. Gjerris, M.; Gaiani, S. Household food waste in Nordic countries: Estimations and ethical implications. J. Appl. Ethics 2013, 7, 6-23. [CrossRef]

75. Graham-Rowe, E.; Jessop, D.C.; Sparks, P. Identifying motivations and barriers to minimising household food waste. Res. Conserv. Recycl. 2014, 84, 15-23. [CrossRef]

76. Van Geffen, L.; Van Herpen, E.; Sijtsema, S.; Van Trijp, H. Food waste as the consequence of competing motivations, lack of opportunities, and insufficient abilities. Res. Conserv. Recycl. 2020, 5, 27-55. [CrossRef]

77. Garske, B. Ordnungsrechtliche und ökonomische Instrumente der Phosphor-Governance. Unter Berücksichtigung der Wirkungen auf Böden, Gewässer, Biodiversität und Klima; Metropolis: Marburg, Germany, 2020.

78. United Nations (UN). United Nations Framework Convention on Climate Change; 1771 UNTS 107; S. Treaty Doc No. 102-138; U.N. Doc. A/AC.237/18 (Part II)/ Add.1; 31 ILM 849 (1992); United Nations: New York, NY, USA, 1992.

79. Ekardt, F.; Wieding, J.; Zorn, A. Paris Agreement, Precautionary Principle and Human Rights: Zero Emissions in Two Decades? Sustainability 2018, 10, 2812. [CrossRef]

80. Ekardt, F.; Wieding, J.; Garske, B.; Stubenrauch, J. Agriculture-related Climate Policies - Law and Governance Issues on the European and Global Level. CCLR 2018, 4, 1-16. [CrossRef]

81. Stubenrauch, J. Phosphor-Governance in Ländervergleichender Perspektive-Deutschland, Costa Rica, Nicaragua. Ein Beitrag zur Nachhaltigkeit- und Bodenschutzpolitik; Metropolis: Marburg, Germany, 2019.

82. European Union (EU). Council Directive 91/676/EEC of 12 December 1991 Concerning the Protection of Waters against Pollution Caused by Nitrates from Agricultural Sources; OJ L 375/1; European Union: Brussels, Belgium, 1991.

83. European Union (EU). Directive 2000/60/EC of the European Parliament and of the Council of 23 October 2000 Establishing a Framework for Community Action in the Field of Water Policy; OJ L 327/1; European Union: Brussels, Belgium, 2000.

84. United Nations (UN). A/68/970, Report of the Open Working Group of the General Assembly on Sustainable Development Goals; 12 August 2014; United Nations: New York, NY, USA, 2014.

85. United Nations (UN). About the Sustainable Development Goals. Available online: https://www.un.org/ sustainabledevelopment/sustainable-development-goals (accessed on 14 May 2020).

86. Pe'er, G.; Lakner, S.; Müller, R.; Passoni, G.; Bontzorlos, V.; Clough, D.; Moreira, F.; Azam, C.; Berger, J.; Bezak, P.; et al. Is the CAP Fit for Purpose? An Evidence-Based Fitness-Check Assessment; German Centre for Integrative Biodiversity Research (iDiv): Halle, Germany; Jena, Germany; Leipzig, Germany, 2017.

87. United Nations (UN). Zero Hunger Challenge. Available online: https://www.un.org/zerohunger (accessed on 15 May 2020).

88. Food and Agriculture Organization of the United Nations (FAO). SAVE FOOD: Global Initiative on Food Loss and Waste Reduction. Available online: http:/ / www.fao.org/save-food/en (accessed on 15 May 2020).

89. Food and Agriculture Organization of the United Nations (FAO). Technical Platform on the Measurement and Reduction of Food Loss and Waste. Available online: http:/ /www.fao.org/platform-food-loss-waste/en/ (accessed on 15 May 2020).

90. European Commission. Communication from the Commission to the European Parliament, the Council, the European Economic and Social Committee and the Committee of the Regions: Roadmap to a Resource Efficient Europe; COM(2011) 517 Final from 20.09.2011; European Commission: Brussels, Belgium, 2011.

91. Council of the European Union. Food Losses and Food Waste: Assessment of Progress Made on the Implementation of June 2016 Council Conclusions; 6659/18 from 28.03.2018; Council of the European Union: Brussels, Belgium, 2018.

92. European Commission. Communication from the Commission to the European Parliament, the Council, the European Economic and Social Committee and the Committee of the Regions: Closing the loop-An EU Action Plan for the Circular Economy; COM(2015) 614 Final from 02.12.2015; European Commission: Brussels, Belgium, 2011.

93. European Commission. EU Platform on Food Losses and Food Waste. Available online: https://ec.europa. eu/food/safety/food_waste/eu_actions/eu-platform_en (accessed on 15 May 2020).

94. European Commission. EU Platform on Food Losses and Food Waste. Terms of Reference (ToR) from 01.07.2019; European Commission: Brussels, Belgium, 2019. 
95. European Commission. Commission Delegated Decision (EU) 2019/1597 of 3 May 2019 Supplementing Directive 2008/98/EC of the European Parliament and of the Council as Regards a Common Methodology and Minimum Quality Requirements for the Uniform Measurement of Levels of Food Waste; OJ L 248/77; European Commission: Brussels, Belgium, 2019.

96. European Commission. Communication from the Commission to the European Parliament, the Council, the European Economic and Social Committee and the Committee of the Regions: The European Green Deal; COM(2019) 640 Final from 11.12.2019; European Commission: Brussels, Belgium, 2019.

97. European Union (EU). Directive (EU) 2018/851 of the European Parliament and of the Council of 30 May 2018 amending Directive 2008/98/EC on Waste; OJ L150/109; European Union: Brussels, Belgium, 2018.

98. European Union (EU). Directive 2008/98/EC of the European Parliament and of the Council of 19 November 2008 on Waste and Repealing Certain Directives; OJ L 312/3; European Union: Brussels, Belgium, 2008.

99. European Union (EU). Regulation (EC) No 178/2002 of the European Parliament and of the Council of 28 January 2002 laying down the general principles and requirements of food law, establishing the European Food Safety Authority and laying down procedures in matters of food safety; OJ L 31/1; European Union: Brussels, Belgium, 2002.

100. Food Loss and Waste Protocol (FLW Protocol). Food Loss and Waste Accounting and Reporting Standard; Version 1.0; World Resources Institute: Washington, DC, USA, 2016.

101. European Union (EU). EU FUSIONS Website. Available online: http://www.eu-fusions.org/ (accessed on 15 May 2020).

102. European Union (EU). REFRESH: Resource Efficient Food and dRink for the Entire Supply cHain. Available online: http:/ / eu-refresh.org/about-refresh (accessed on 15 May 2020).

103. Massot, M.A. Research for AGRI Committee-The Farm to Fork Strategy Implications for Agriculture and the CAP; European Parliament, Policy Department for Structural and Cohesion Policies: Brussels, Belgium, 2020.

104. European Union (EU). Consolidated Version of the Treaty on the Functioning of the European Union; OJ C 202/1; European Union: Brussels, Belgium, 2016.

105. EUROSTAT. Household Consumption Expenditure in the EU. Household Expenditure by Purpose in the EU. 2016. Available online: https:/ / ec.europa.eu/ eurostat/news/themes-in-the-spotlight/householdexpenditure-2016 (accessed on 15 May 2020).

106. European Union (EU). Regulation (EU) No 1305/2013 of the European Parliament and of the Council of 17 December 2013 on Support for Rural Development by the European Agricultural Fund for Rural Development (EAFRD) and Repealing Council Regulation (EC) No 1698/2005; OJ L347/487; European Union: Brussels, Belgium, 2013.

107. European Commission. Proposal for a Regulation of the European Parliament and of the Council establishing rules on support for strategic plans to be drawn up by Member States under the Common agricultural policy (CAP Strategic Plans) and financed by the European Agricultural Guarantee Fund (EAGF) and by the European Agricultural Fund for Rural Development (EAFRD) and repealing Regulation (EU) No 1305/2013 of the European Parliament and of the Council and Regulation (EU) No 1307/2013 of the European Parliament and of the Council; COM(2018) 392 Final from 01.06.2018; European Commission: Brussels, Belgium, 2018.

108. European Commission. Proposal for a Regulation of the European Parliament and of the Council on the Financing, Management and Monitoring of the Common Agricultural Policy and Repealing Regulation (EU) No 1306/2013; $\operatorname{COM}(2018) 393$ Final from 01.06.2018; European Commission: Brussels, Belgium, 2018.

109. European Commission. Proposal for a Regulation of the European Parliament and of the Council Amending Regulations (EU) No 1308/2013 Establishing a Common Organisation of the Markets in Agricultural Products, (EU) No 1151/2012 on Quality Schemes for Agricultural Products and Foodstuffs, (EU) No 251/2014 on the Definition, Description, Presentation, Labelling and the Protection of Geographical Indications of Aromatised Wine Products, (EU) No 228/2013 Laying Down Specific Measures for Agriculture in the Outermost Regions of the Union and (EU) No 229/2013 Laying down Specific Measures for Agriculture in Favour of the Smaller Aegean Islands; COM(2018) 394 Final from 01.06.2018; European Commission: Brussels, Belgium, 2018.

110. European Court of Auditors (ECA). Opinion No 7/2018 (Pursuant to Article 322(1)(a) TFEU) Concerning Commission Proposals for Regulations Relating to the Common Agricultural Policy for the Post-2020 Period (COM(2018) 392, 393 and 394 Final); European Court of Auditors: Luxembourg, 2018.

111. European Union (EU). Regulation (EU) No 1307/2013 of the European Parliament and of the Council of 17 December 2013 Establishing Rules for Direct Payments to Farmers under Support Schemes within the Framework of the Common Agricultural Policy and Repealing Council Regulation (EC) No 637/2008 and Council Regulation (EC) No 73/2009; OJ L 347/608; European Union: Brussels, Belgium, 2013. 
112. Pe'er, G.; Bonn, A.; Bruelheide, H.; Dieker, P.; Eisenhauer, N.; Feindt, P.H.; Hagedorn, G.; Hansjürgens, B.; Herzon, I.; Lomba, Â.; et al. Action needed for the EU Common Agricultural Policy to adress sustainability challenges. People Nat. 2020, 2, 305-316. [CrossRef]

113. Hagedorn, W.; Wilts, H. Who should waste less? Food waste prevention and rebound effects in the context of the Sustainable Development Goals. GAIA 2019, 28, 119-125. [CrossRef]

114. European Union (EU). Regulation (EU) No 1308/2013 of the European Parliament and of the Council of 17 December 2013 Establishing a Common Organisation of the Markets in Agricultural Products and Repealing Council Regulations (EEC) No 922/72, (EEC) No 234/79, (EC) No 1037/2001 and (EC) No 1234/2007; OJ L 347/671; European Union: Brussels, Belgium, 2013.

115. European Union (EU). Directive 2011/91/EU of the European Parliament and of the Council of 13 December 2011 on Indications or Marks Identifying the Lot to Which a Foodstuff Belongs; OJ L 334/1; European Union: Brussels, Belgium, 2011.

116. Aramyan, L.; Valeva, N. FUSIONS. The Netherlands-Country report on National Food Waste Policy; FUSIONS: Wageningen, The Netherlands, 2016.

117. Garske, B.; Stubenrauch, J.; Ekardt, F.; Weisse, C.F.; Lorenz, M. Kunststoffe im europäischen Kreislaufwirtschafts- und Stoffrecht. NuR 2020, 4, 215-224.

118. Gollnhofer, F.; Boller, D. The Evolution of the German Anti-food Waste Movement: Turning Sustaianble Ideas into Business. In Food Waste Management. Solving the Wicket Problem; Närvänen, E., Mesiranta, N., Mattila, M., Heikkinen, A., Eds.; Palgrave Macmillan: London, UK, 2020; pp. 115-139.

119. Waarts, Y.; Eppink, M.; Oosterkamp, E.; van der Sluis, A.; Timmermans, T. Reducing Food Waste: Obstacles Experienced in Legislation and Regulations; University and Research Centre Wageningen: Wageningen, The Netherlands, 2011.

120. European Union (EU). Regulation (EU) No 1169/2011 of the European Parliament and of the Council of 25 October 2011 on the Provision of Food Information to Consumers, Amending Regulations (EC) No 1924/2006 and (EC) No 1925/2006 of the European Parliament and of the Council, and repealing Commission Directive 87/250/EEC, Council Directive 90/496/EEC, Commission Directive 1999/10/EC, Directive 2000/13/EC of the European Parliament and of the Council, Commission Directives 2002/67/EC and 2008/5/EC and Commission Regulation (EC) No 608/2004; OJ L 304/18; European Union: Brussels, Belgium, 2011.

121. Vinegar, R.; Parker, P.; McCourt, G. More than a response to food insecurity: Demographics and social networts of urban dumpster divers. Int. Justice Sustain. 2013, 21, 241-253. [CrossRef]

122. Bayerisches Oberstes Landesgericht. Beschluss vom 02.10.2019, Aktenzeichen 206 StRR 1013/19 und 206 StRR 1015/19; Bayerisches Oberstes Landesgericht: Munich, Germany, 2019.

123. Giordano, C.; Falasconi, L.; Cicatiello, C.; Pancino, B. The role of food waste hierarchy in addressing policy and research: A comparative analysis. J. Clean. Prod. 2020, 252, 119617. [CrossRef]

124. Openpetition. Welfare: Gesetzliches Lebensmittelwegwerfverbot für Deutschland (wie seit 2016 auch in Frankreich) gefordert. Available online: https://www.openpetition.de/petition/online/ gesetziches-lebensmittel-wegwerfverbot-fuer-deutschland-wie-seit-2016-auch-in-frankreich-gefordert (accessed on 19 May 2020).

125. Deutscher Bundestag. Petition 76034. Lebensmittel-Wegwerfverbot vom 09.01.2018. Available online: https: / / epetitionen.bundestag.de/petitionen/_2018/_01/_09/Petition_76034.nc.html (accessed on 19 May 2020).

126. OLIO. Share More. Waste Less. Available online: https:/ / oliox.com (accessed on 19 May 2020).

127. Foodrescue. Hunger in the United States makes no sense. Available online: https://foodrescue.us (accessed on 19 May 2020).

128. Foodsharing. Willkommen bei Foodsharing! Available online: https:/ foodsharing.de/ (accessed on 19 May 2020).

129. Italian Parliament. Legge 19 agosto 2016, n. 166: Disposizioni Concernenti la Donazione e la Distribuzione di Prodotti Alimentari e Farmaceutici a fini di Solidarieta' Sociale e per la Limitazione Degli Sprechi (16G00179); Gazetta Ufficale Serie Generale n. 202; Italian Parliament: Rome, Italy, 2016.

130. European Union (EU). Regulation (EU) No 223/2014 of the European Parliament and of the Council of 11 March 2014 on the Fund for European Aid to the Most Deprived; OJ L 72/1; European Union: Brussels, Belgium, 2014.

131. European Union (EU). Council Directive 2006/112/EC of 28 November 2006 on the Common System of Value Added Tax; OJ L 347/1; European Union: Brussels, Belgium, 2006.

132. European Commission. Proposal for a Directive of the European Parliament and of the Council amending Directive 2008/98/EC on Waste; COM(2015) 595 Final from 02.12.2015; European Commission: Brussels, Belgium, 2015. 
133. Wurzel, R.; Zito, A.; Jordan, A. Smart (and Not-So-Smart) Mixes of New Environmental Policy Instruments. In Smart Mixes for Transboundary Environmental Harm; Van Erp, J., Faure, M., Nollkaemper, A., Philipsen, N., Eds.; Cambridge University Press: Cambride, UK, 2019; pp. 69-94.

134. Principato, L. Food Waste at Consumer Level: A Comprehensive Literature Review; Springer International Publishing: Charm, Switzerland, 2018.

135. De Visser-Amundson, A; Kleinjnen, M. Nudging in Food Waste Management: Where Sustainable Meeds Cost-Effectiveness. In Food Waste Management: Solving the Wicket Problem; Närvänen, E., Mesiranta, N., Mattila, M., Heikkinen, A., Eds.; Palgrave Macmillan: London, UK, 2020; pp. 57-87.

136. Danish Council on Ethics. The Ethical Consumer: Climate Damaging Foods; The Danish Council on Ethics: Copenhagen, Denmark, 2016.

137. Rockström, J.; Gaffney, O.; Rogelj, J.; Meinshausen, M.; Nakicenovic, N.; Schellnhuber, H.J. A roadmap for rapid decarbonization. Emissions inevitably apporach zero with a "carbon law". Science 2017, 335, 1269-1271. [CrossRef]

138. Steffen, W.; Rockström, J.; Richardson, K.; Lenton, T.M.; Folke, C.; Liverman, D.; Summerhayes, C.P.; Barnosky, A.D.; Cornell, S.E.; Crucifix, M.; et al. Trajectories of the Earth System in the Anthropocene. Proc. Natl. Acad. Sci. USA 2018, 115, 8252-8259. [CrossRef] [PubMed]

(C) 2020 by the authors. Licensee MDPI, Basel, Switzerland. This article is an open access article distributed under the terms and conditions of the Creative Commons Attribution (CC BY) license (http://creativecommons.org/licenses/by/4.0/). 